Diabetologia 8, 244-249 (1972)

(C) by Springer-Verlag 1972

\title{
ORIGINALS
}

\section{Insulin Fixation and Glucose Uptake by Forearm Tissues in Response to Infusions of Physiological Amounts of Insulin in Non-diabetic Subjects}

\author{
E. Rasio, M.J. Whichelow, W.J.H. Butterfield and B.H. Hicks \\ Department of Pathophysiology, University of Brussels, Brussels, Belgium \\ Department of Medicine, Guy's Hospital Medical School, London, England
}

Received: March 21, 1972, accepted: April 26, 1972

Summary. Insulin fixation and glucose uptake have been studied in the forearm tissues of nine lean non-diabetic men for three consecutive hours, during a fasting state, an intra-arterial infusion of a small dose of insulin $(25-100 \mathrm{mU})$ and a recovery period. When insulin was administered, the arterial plasma immuno-reactive insulin rose to levels ranging from 15 to $65 \mu \mathrm{U} / \mathrm{ml}$; the tissue insulin fixation was significantly increased during this period, but no effect on tissue glucose uptake was observed. A close correlation was found between the arterial plasma insulin concentration and the tissue insulin fixation. - The injection of $200 \mathrm{mg}$ glucose intraarterially at the end of the study resulted in a reversal of the arterio-venous gradient of plasma insulin concentration. - The results show that large amounts of circulating insulin can be bound to the forearm tissues without exerting an effect on glucose uptake. It is suggested that the binding of insulin occurs at the vascular endothelium and that it is reversible by increased concentrations of blood glucose.

Fixation de l'insuline et captation du glucose par les tissus de l'avant-bras en, réponse a des perfusions de quantés physiologiques d'insuline chez des sujets non-diabètiques

Résumé. La fixation d'insuline et la captation de glucose par les tissus de l'avant-bras ont été étudiées chez 9 sujets non diabétiques de poids normal, au cours de 3 périodes d'observation d'une heure chacune: à jeun, pendant la perfusion intra-artérielle de petites doses d'insuline $(25-100 \mathrm{mU})$ et après l'arrêt de la perfusion. Pendant l'administration d'insuline, l'insuline plasmatique dans l'artère a atteint des taux variant de 15 à 65 $\mu \mathrm{U} / \mathrm{ml}$; simultanément, la fixation d'insuline aux tissus de l'avantbras s'est élevée de façon significative mais aucun effet sur la captation de glucose n'a été observé. Il existe une étroite corrélation entre les taux d'insuline plasmatique dans l'artère et la fixation d'insuline aux tissus. - Au terme des épreuves, $200 \mathrm{mg}$ de glucose en solution saline ont été injectés par voi intra-artérielle dans l'avant-bras et ont provoqué l'inversion du gradient artério-veineux de concentration plasmatique d'insuline. - Les résultats montrent que des quantités appréciables d'insuline circulante peuvent être fixées par les tissus de l'avant-bras sans exercer d'effet sur la captation de glucose. Il est possible que l'insuline se lie à l'endothélium capillaire et qu'elle en soit libérée par un accroissement du taux de glucose sanguin.

Insulinfixation und Glucoseaufnahme durch das Vorderarmgewebe nach Infusion von physiologischen Mengen von Insulin bei nicht-diabetischen Versuchspersonen

Zusammenfassung. Am Vorderarmgewebe von 9 normalgewichtigen, nicht-diabetischen Versuchspersonen, wurde die Insulinfixation und die Glucoseaufnahme in 3 aufeinanderfolgenden Stunden gemessen: Während des nüchternen Zustandes, während einer intraarteriellen Infusion von kleinen Insulinmengen (25 bis $100 \mathrm{mE}$ ) und einer Erholungsphase. Wenn Insulin verabfolgt wurde, stieg der Plasmaspiegel des arteriellen immunoreaktiven Insulins auf Werte von 15 bis $65 \mu \mathrm{E} / \mathrm{ml}$. Die Fixation des Insulins im Gewebe stieg während dieser Periode signifikant an; ein Effekt auf die Glucoseaufnahme des Gewebes wurde aber nicht beobachtet. Zwischen der Konzentration des arteriellen Plasmainsulins und der Fixation des Insulins im Gewebe ließ sich eine enge Korrelation feststellen. - Die Injektion von $200 \mathrm{mg}$ Glucose intraarteriell am Ende der Untersuchung ergab eine Umkehr des arterio-venösen Gradienten der Insulinkonzentration im Plasma. - Die Ergebnisse zeigen, daß große Mengen von zirkulierendem Insulin an das Gewebe des Vorderarms gebunden werden können, ohne daß sie einen Effekt auf die Glucoseaufnahme ausüben. Man muß annehmen, daß die Insulinbindung am Gefäßendothel erfolgt und daß sie durch steigende Konzentration der Blutglucose reversibel ist.

Key words: Human forearm, tissue insulin fixation, peripheral cell glucose uptake, vascular endothelium.

\section{Introduction}

In normal subjects, a rapid intra-arterial injection of $0.1 \mathrm{U}$ of crystalline insulin increases glucose uptake by the forearm tissues $[1,2]$. In other studies where ${ }^{131}$ I-insulin was used, a relationship was found between the insulin concentration achieved by the injection in the forearm circulation and the amount of insulin leaving the circulation or "fixed" by the tissues. Furthermore, there was a significant correlation between the insulin fixed and the subsequent increase in glucose uptake [3]. In diabetic subjects, although the relationship between glucose uptake and insulin fixation remained unchanged, insulin fixation was low for the concentration achieved in the blood. This suggested a block to insulin removal from the circulation in diabetes, and it was postulated that the block was at the level of the capillary endothelium.

It has been shown as a result of studies in dogs using low doses of ${ }^{125}$ I-insulin, that the capillaries may adsorb insulin which can later be displaced into the circulation by the injection of larger quantities of unlabelled insulin or small amounts of glucose [4]. 
In studies of insulin fixation in man [3], the doses of insulin which were administered $(0.1 \mathrm{U})$ induced a much higher plasma insulin concentration (300 to $937 \mu \mathrm{U} / \mathrm{ml}$ ) than that normally encountered in man even after oral glucose loading, where insulin levels range up to $200 \mu \mathrm{U} / \mathrm{ml}[5]$. We have now studied the effects of lower, physiological doses of insulin on insulin fixation and glucose uptake in the forearm tissues of normal subjects and have also investigated the possibility that insulin could be dislodged from its site of fixation by glucose.

\section{Subjects and Methods}

Table 1 shows the details of the nine lean men who volunteered for these studies. They were either hospital staff or convalescent patients in a general medical ward. None had any disease or were receiving any drugs known to be associated with carbohydrate intolerance; all had normal fasting blood sugar below $88 \mathrm{mg} \%$. The subjects were studied after an overnight fast, lying comfortably on a hospital bed.

The forearm technique was used as described previously [6], with some modifications. Two catheters were inserted into the brachial artery, one directed proximally and the other distally, with the tips 18 to $23 \mathrm{~cm}$ apart. The proximally directed catheter was used for the insulin and glucose infusion and the distally directed one for arterial blood sampling. Venous blood was collected through a third catheter located in an anticubital vein draining the deep forearm tissues in the same arm. All catheters were kept patent by the infusion of $0.33 \mathrm{ml} / \mathrm{min}$ of normal saline without heparin.

Forearm blood flow was measured with a venous occlusion plethysmograph during blood sampling, when the wrist cuff was inflated to $200 \mathrm{~mm} \mathrm{Hg}$.

The investigations were divided into three periods, each of one hour. During the first hour, the basal state was assessed. During the second hour, crystalline insulin (Actrapid Novo, Copenhagen) was infused at a steady rate of $0.33 \mathrm{ml} / \mathrm{min}$; three subjects received $25 \mathrm{mU}$, two subjects $50 \mathrm{mU}$ and four subjects $100 \mathrm{mU}$ (Table 1 ). The insulin was diluted with normal saline and no precautions, such as the addition of albumin, were taken to prevent adsorption to the glass or plastic walls of the containers and catheters used [7]. Observations were continued during the third hour, when no insulin was given.

At the end of the third hour, an additional investigation was carried out: $200 \mathrm{mg}$ glucose in $2 \mathrm{ml}$ salino were given through the proximal arterial catheter over $2 \mathrm{~min}$; distal arterial and venous concentrations of plasma immunoreactive insulin (IRI) were measured over minute periods for 4 min following the start of the infusion.
Plasma insulin [8] and blood glucose were measured in duplicate on blood samples drawn simultaneously every $10 \mathrm{~min}$ throughout the $3 \mathrm{~h}$. Insulin fixation was calculated by the use of the Fick equation, from arterio-venous differences of plasma IRI and plasma flow, which was taken as $55 \%$ of the blood flow. Cell glucose uptake was calculated as described previously $[9,3]$.

Results in Figs. 1 and 2 are presented as mean values for the group as a whole. Indeed, despite the infusion of variable amounts of insulin, differences in both blood flow and insulin adsorption to the perfusion apparatus resulted in variations of plasma insulin levels which were, percentagewise, similar to those seen in the basal state.

\section{Results}

The arterial glucose concentration remained steady throughout the tests (Fig. 1). The arterio-venous blood glucose differences fluctuated, but no overall change occurred during any phase. There was a threefold increase in the distal arterial plasma insulin levels during the insulin infusion with a significant increase

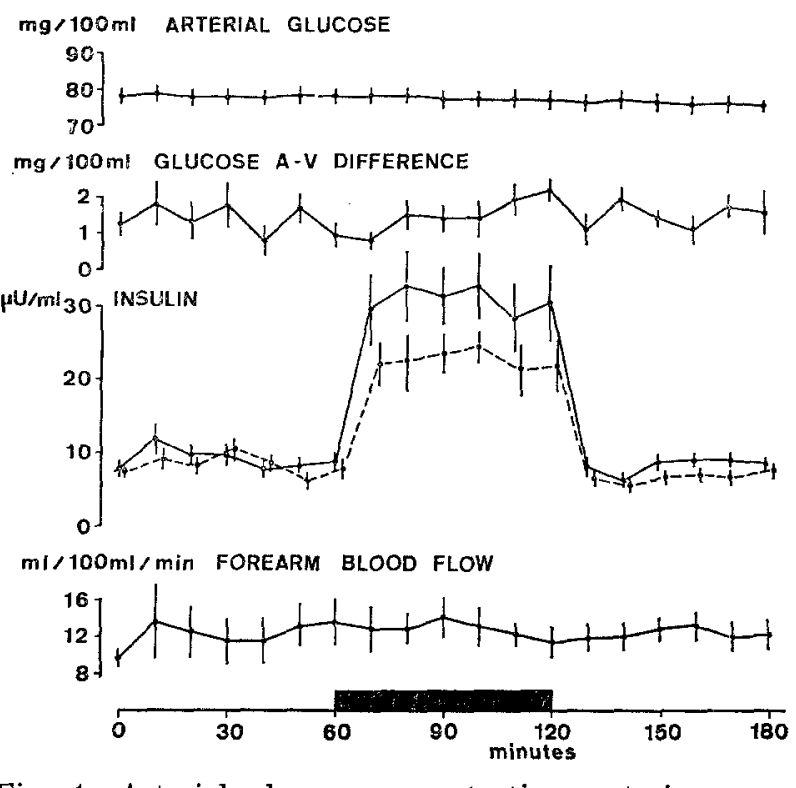

Fig. 1. Arterial glucose concentration, arterio-venous glucose difference, arterial and venous insulin concentrations and forearm blood flow. Mean values \pm SEM. Bar shows duration of insulin injection

Table 1. Details of subjects studied

\begin{tabular}{|c|c|c|c|c|c|c|c|c|}
\hline Subject & $\begin{array}{l}\text { Age } \\
\text { years }\end{array}$ & $\begin{array}{l}\text { Weight } \\
\mathrm{kg}\end{array}$ & $\begin{array}{l}\text { Height } \\
\mathrm{cm}\end{array}$ & $\begin{array}{l}\text { Subscapular } \\
\text { Skinfold } \\
\text { Thickness } \\
\text { em }\end{array}$ & $\begin{array}{l}\text { Forearm } \\
\text { Volume } \\
\mathrm{ml}\end{array}$ & Diagnosis & $\begin{array}{l}\text { Mean } \\
\text { FBS } \\
\text { mg\% }\end{array}$ & $\begin{array}{l}\text { Insulin } \\
\text { Dose } \\
\text { mU }\end{array}$ \\
\hline $\begin{array}{l}1 \\
2 \\
3 \\
4 \\
5 \\
6 \\
7 \\
8 \\
9\end{array}$ & $\begin{array}{l}45 \\
34 \\
60 \\
30 \\
24 \\
27 \\
47 \\
64 \\
28\end{array}$ & $\begin{array}{l}50 \\
70 \\
61 \\
56 \\
57 \\
91 \\
67 \\
69 \\
76\end{array}$ & $\begin{array}{l}168 \\
181 \\
177 \\
157 \\
175 \\
179 \\
173 \\
172 \\
172\end{array}$ & $\begin{array}{l}1.0 \\
0.7 \\
1.1 \\
1.3 \\
0.8 \\
1.7 \\
1.2 \\
1.3 \\
1.2\end{array}$ & $\begin{array}{l}370 \\
580 \\
520 \\
540 \\
540 \\
630 \\
575 \\
700 \\
580\end{array}$ & $\begin{array}{l}\text { Asthma } \\
\text { Normal } \\
\text { Lumbago } \\
\text { Normal } \\
\text { Normal } \\
\text { Normal } \\
\text { Anxiety } \\
\text { Bronchitis } \\
\text { Normal }\end{array}$ & $\begin{array}{l}69.5 \\
83.5 \\
77.0 \\
73.0 \\
82.5 \\
87.5 \\
77.5 \\
79.0 \\
76.5\end{array}$ & $\begin{array}{r}25 \\
25 \\
25 \\
50 \\
50 \\
100 \\
100 \\
100 \\
100\end{array}$ \\
\hline
\end{tabular}


of the arterio-venous difference $(P<0.05)$. Although there were individual variations in blood flow from one period to another (Table 2), there were no consistent changes.

The mean value for insulin fixation during the basal period was $11 \mu \mathrm{U} / 100 \mathrm{ml}$ forearm/min, rising to $54 \mu \mathrm{U} / 100 \mathrm{ml}$ forearm/min during the insulin infusion. The change is of borderline significance $(P \simeq 0.05)$ but

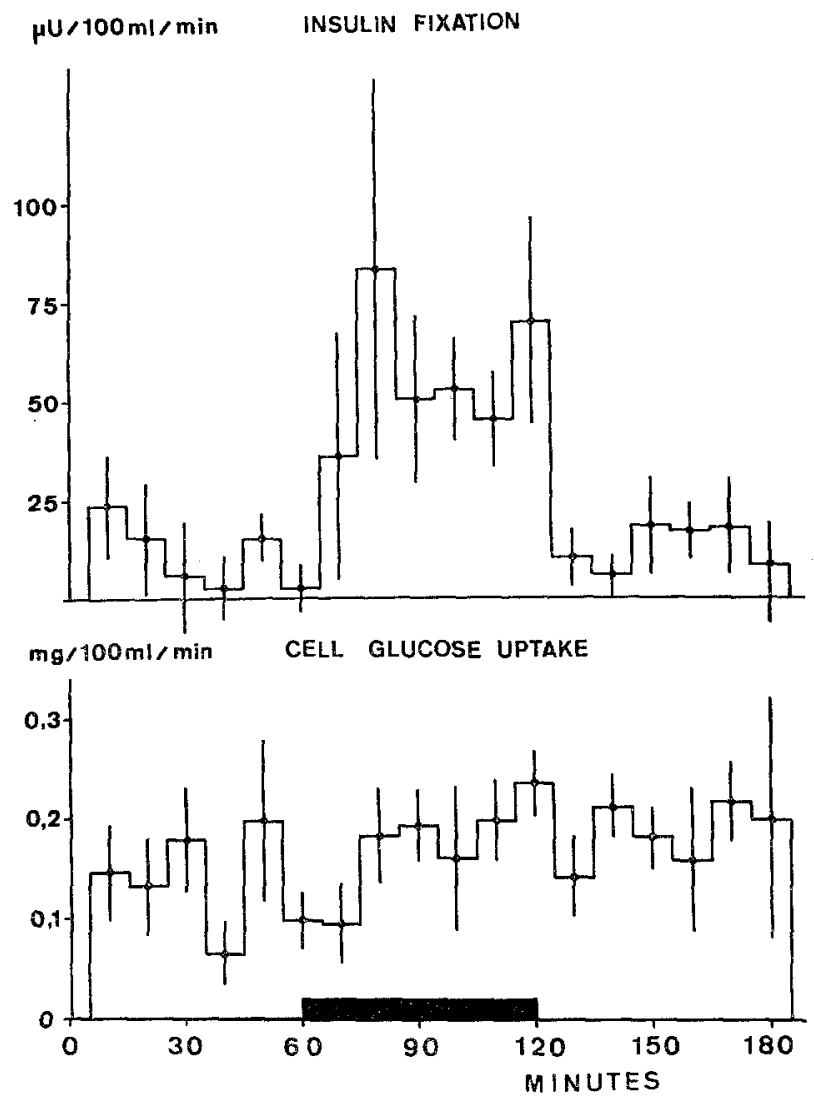

Fig. 2. Insulin fixation and glucose uptake values in nine subjects. Mean values \pm SEM. Bar shows duration of insulin injection

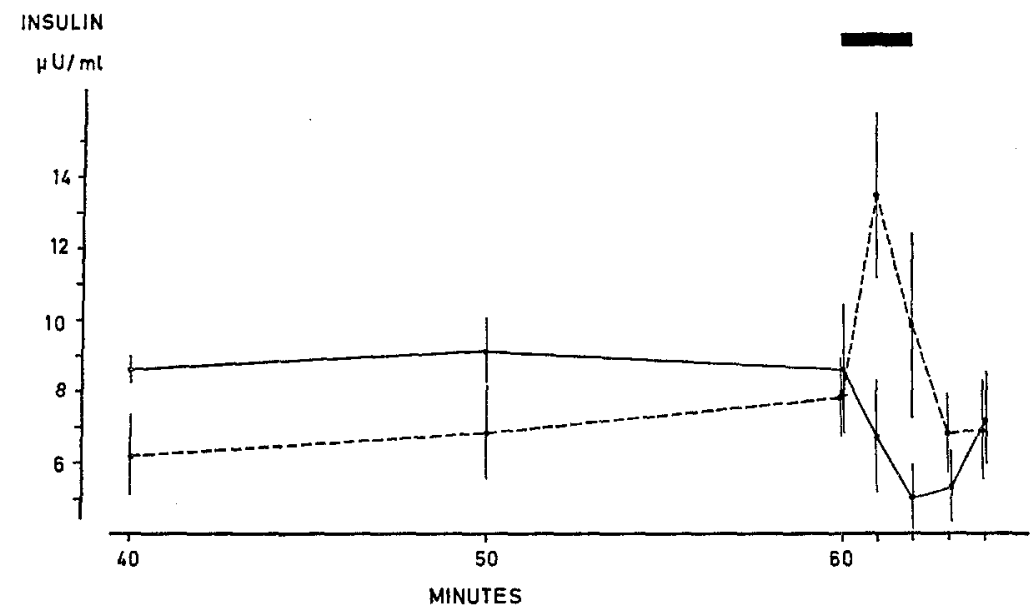

Fig. 4. Effect of injection of $200 \mathrm{mg}$ glucose intra-arterially on arterial (solid line) and venous (dotted line) IRI levels in seven subjects. Mean values \pm SEM. Bar shows duration of glucose infusion when only the subjects given the $100 \mathrm{mU}$ dose are considered, the increase of insulin fixation is significant $(P<0.05)$ (Fig. 2 and Table 2$)$. After the end of the infusion, insulin fixation levels fell immediately towards the basal values, to $14 \mu \mathrm{U} / 100 \mathrm{ml}$ forearm/min. No changes were observed in cell glucose uptake during the periods of saline or insulin infusion. mean arterial plasma IRI concentration in any one period for any one individual and the corresponding mean insulin fixation level $(r=0.710, n=26, P<$ 0.001 ). No correlation was found between cell glucose uptake and tissue insulin fixation nor between cell glu.cose uptake and arterial plasma insulin concentration.

Fig. 4 shows the effect of infusing glucose intraarterially over two minutes on the arterial and venous

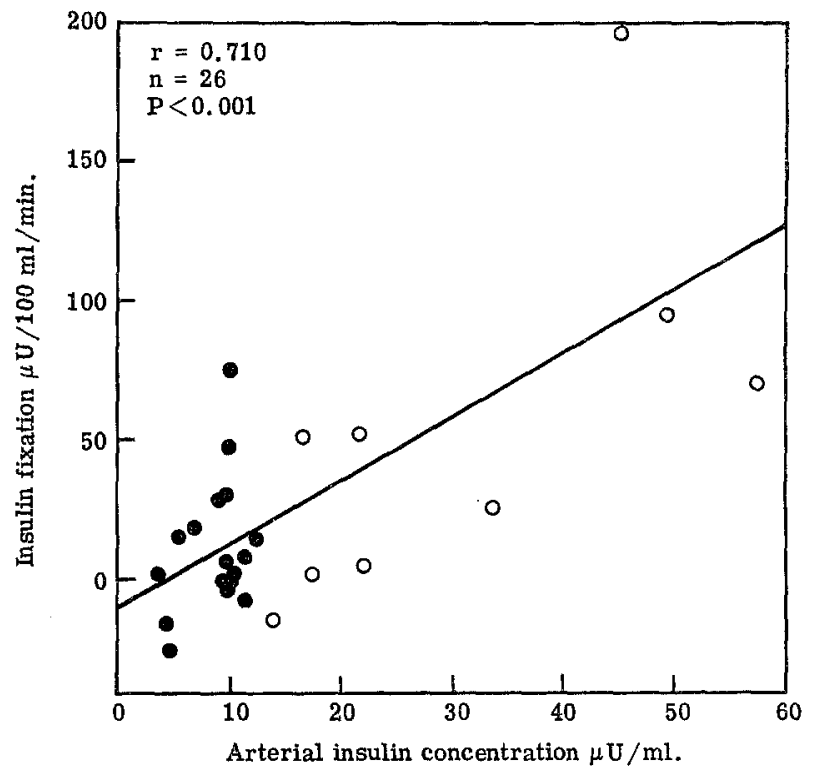

Fig. 3. Relationship between arterial plasma insulin concentration and tissue insulin fixation in basal, infusion and post infusion periods. Values for infusion period shown as open circles
There was a close correlation (Fig. 3) between the 
plasma IRI values, in seven subjects. During the infusion, the venous plasma IRI level rose significantly $(P<0.05)$ by an average of $6 \mu \mathrm{U} / \mathrm{ml}$, and the arterial level decreased. The mean arterio-venous. IRI differ ence became negative $(P<0.05)$. The individual results are shown in Table 3. Blood flow was not affected by the injection of glucose in six subjects in whom it was measured (data not shown).

\section{Discussion}

A difficulty in this investigation was ensuring adequate mixing in the arterial blood of the injected insulin. In three subjects, Evan's Blue was infused through the proximal arterial catheter and samples taken simultaneously from the distal arterial and the venous catheters. The dye dilution curves for both ourselves $[1,10]$ and other workers $[2,11]$ in which only one arterial catheter was used. The mean flow in the present study was 12.4 ( $\pm 5.3 \mathrm{~S} . \mathrm{D}$.) $\mathrm{ml} / 100 \mathrm{ml} / \mathrm{min}$, compared to a mean of $5.2( \pm 1.5 \mathrm{~S} . \mathrm{D}$.) $\mathrm{ml} / 100 \mathrm{ml} / \mathrm{min}$ in one-catheter studies and to an even lower value of 3.4 ( $\pm 0.9 \mathrm{~S}$.D.) $\mathrm{ml} / 100 \mathrm{ml} / \mathrm{min}$ in arms without arterial catheterization. None of the subjects complained of discomfort in the arm and, since the flow rate was unaffected by substituting Hartman's solution for saline or by stopping the infusion, altogether, the high blood flows did not result from the greater quantity of saline infused $(0.6 \mathrm{ml} / \mathrm{min}$ as opposed to $0.3 \mathrm{ml} / \mathrm{min}$ in studies using one arterial catheter). These high blood flows seem to be associated with the presence of two catheters in the artery. They did not appear to influence glucose uptake, since the values in the basal state (Table 2) are well within the ranges found previously $[1,3]$.

Table 2. Results during basal (I), insulin infusion (II) and post insulin infusion (III) periods in all subjects

\begin{tabular}{|c|c|c|c|c|c|c|c|c|c|c|}
\hline \multirow[t]{3}{*}{ Subject } & \multirow{3}{*}{$\begin{array}{l}\text { Insulin } \\
\text { dose } \\
\mathrm{mU} / \mathrm{h}\end{array}$} & \multicolumn{3}{|c|}{ Forearm blood flow } & \multicolumn{3}{|c|}{ Cell glucose uptake } & \multicolumn{3}{|c|}{ Insulin fixation } \\
\hline & & \multicolumn{3}{|c|}{$\mathrm{ml} / 100 \mathrm{ml} / \mathrm{min}$} & \multicolumn{3}{|c|}{$\mathrm{mg} / 100 \mathrm{ml} / \mathrm{min}$} & \multicolumn{3}{|c|}{$\mu \mathrm{U} / 100 \mathrm{ml} / \mathrm{min}$} \\
\hline & & & II & III & & II & III & I & II & III \\
\hline 1 & 25 & 32.7 & 19.6 & 16.2 & 0.033 & 0.139 & 0.174 & 74 & 51 & 17 \\
\hline 2 & 25 & 7.5 & 6.2 & 14.4 & 0.166 & 0.180 & 0.184 & 9 & 6 & 8 \\
\hline 3 & 25 & 15.9 & 20.3 & 14.2 & 0.137 & 0.267 & 0.242 & -25 & 3 & 20 \\
\hline 4 & 50 & 5.8 & 9.5 & 8.6 & 0.037 & 0.067 & 0.067 & 2 & -13 & -14 \\
\hline 5 & 50 & 12.1 & 15.3 & 14.3 & 0.285 & 0.236 & 0.282 & 32 & 196 & 30 \\
\hline 6 & 100 & 9.4 & 9.6 & 8.1 & 0.120 & 0.178 & 0.135 & 15 & 95 & -1 \\
\hline 7 & 100 & 12.2 & 16.0 & 15.0 & 0.250 & 0.255 & 0.290 & 0 & 53 & 48 \\
\hline 8 & 100 & 8.1 & 9.7 & - & 0.031 & 0.171 & - & -8 & 27 & - \\
\hline 9 & 100 & 7.7 & 8.1 & 7.4 & 0.188 & 0.137 & 0.137 & 0 & 71 & 3 \\
\hline & Mean & 12.4 & 12.7 & 12.3 & 0.139 & 0.181 & 0.189 & 11 & $54^{a}$ & 14 \\
\hline & SEM & 2.8 & 1.7 & 1.3 & 0.032 & 0.029 & 0.028 & 9 & 21 & 7 \\
\hline
\end{tabular}

a $P=0.05$ ( $t$-test; difference from control value)

Table 3. Arterio-venous differences of plasma insulin levels before and after intra-arterial glucose injection. Values are in $\mu U / m l$

Time in relation to glucose injection (min)

\begin{tabular}{|c|c|c|c|c|c|c|c|}
\hline Subject & -20 & -10 & 0 & +1 & +2 & +3 & +4 \\
\hline $\begin{array}{l}1 \\
3\end{array}$ & 3.5 & 0.5 & 0 & -2.0 & -3.5 & 3.0 & 7.0 \\
\hline 4 & 6.5 & 3.5 & -1.0 & -14.0 & 2.5 & -2.0 & -0.5 \\
\hline 5 & 1.5 & -0.5 & -3.0 & -2.5 & -2.5 & -8.0 & -7.0 \\
\hline 6 & 2.5 & 2.5 & 0 & -14.0 & -11.5 & -2.0 & -0.5 \\
\hline 7 & -3.5 & 2.5 & 0.5 & -10.0 & -11.5 & -1.0 & 0 \\
\hline 9 & 6.0 & 13.0 & 10.0 & 2.0 & 2.5 & 0.5 & 4.5 \\
\hline & -0.5 & -1.0 & 0 & -7.0 & -10.0 & 0 & -2.0 \\
\hline
\end{tabular}

catheters were similar, from which we conclude that the catheterized vein was supplied largely by the brachial artery and adequate mixing had occurred between the tips of the proximal and distal arterial catheters (data not shown).

\section{Blood Flow}

The levels of blood flow observed in these investigations, in which two catheters were inserted in the artery, were higher in subjects Nos. 1, 2, 3, 5 and 7 (Table 2) than those found in previous studies by
The level of blood flow did not affect the comparison of glucose uptake and insulin fixation at any one time since glucose and IRI estimations were carried out on the same blood samples. Moreover, since the blood flow remained relatively steady for the duration of the test, changes in venous levels of IRI and glucose cannot be the results of changes in blood flow.

\section{Insulin Fixation and Glucose Uptake}

Distal arterial insulin concentrations which averaged $9 \mu \mathrm{U} / \mathrm{ml}$ during the basal period, were raised to a 
mean of $31 \mu \mathrm{U} / \mathrm{ml}$ by the insulin infusion (Fig. 1). The individual values $(15-65 \mu \mathrm{U} / \mathrm{ml})$ were within the levels normally seen during intravenous glucose tolerance tests [12]. Venous levels also rose during the insulin infusion but the rise was less than that in the artery. It can be calculated that during the entire hour of this phase $18,000 \mu \mathrm{U}$ of insulin were fixed to the tissues, that is about one third of the arerage dose administered.

No effect on glucose uptake could be detected despite the significant increase in insulin fixation (Fig. 2). This is in agreement with reports of other workers, who also found no glucose response to physiological levels of endogenous or exogenous insulin $[13,14,15]$. Thus, while insulin is disappearing from the circulation, it is apparently not acting at a cellular level to increase glucose uptake. It has been shown that there can be insulin fixation to the hind limb tissues of the dog during insulin infusion without any increase in the levels of insulin in the leg lymph $[4,16]$. It is possible, therefore, that under the circumstances of normoglycemia which were obtained in the present investigations, insulin at physiological levels did not traverse the vascular endothelium to reach the interstitial fluid, but remained attached to the blood vessels.

The close correlation found between the concentration of IRI in the plasma and IRI fixation confirms and extends the findings of previous studies where higher levels of insulin were achieved [3]. The absence of any correlation between glucose uptake and insulin fixation at physiological levels is in harmony with the hypothesis that there is a threshold insulin concentration level which has to be exceeded for insulin to exert its metabolic effect on glucose uptake, at any rate when blood sugar levels are low, as in the fasting state [4].

Pheripheral glucose uptake is increased when the levels of insulin are raised by the administration of glucose, either orally $[1,10,17]$ or intravenously [18, 19], and the glucose effect is undoubtedly dependent on the presence of circulating insulin. During such studies, the threshold may have been overcome by higher insulin levels than obtained in these investigations. Alternatively, it is possible that the raised levels of glucose dislodge insulin bound to the vascular endothelium, allowing some insulin to pass into the interstitial fluid and stimulate cell glucose uptake. It is of interest therefore that in the present study we were able to demonstrate in man that venous levels of insulin were increased by the intra-arterial infusion of glucose; as there was no sudden drop in blood flow, the effect was not due to insulin being released at the same rate into a smaller volume of blood flowing through the forearm. The reversal of the arterio-venous gradient of plasma insulin level is consistent with the displacement of insulin from binding sites in the tissues of the forearm. The displacement is evident even if there had not been a substantial fall in the arterial concentration of plasma insulin, a phenomenon for which we have no explanation. A similar action of intra-arterial glucose in the dog has been reported and discussed elsewhere [20]. If glucose does exert a local influence on insulin binding, as postulated, it could provide a hitherto unrecognized but potentially important factor in the auto-regulation of glucose uptake.

Acknowledgements: We are grateful to Dr. A.C. Asmal, Dr. H.A. Ooms, Staff Nurse M. Brown and Miss E. Houghton for valuable assistance in these studies.

Dr. E. Rasio was in receipt of grants from the Wellcome Trust, the U. S. P.H.S. (No TWOO 289-03) and the F.R.S.M. (No 925).

\section{References}

1. Butterfield, W.J.H., Whichelow, M.J.: Peripheral glucose metabolism in control subjects and diabetic patients during glucose, glucose insulin and insulin. sensitivity tests. Diabetologia 1, 43-53 (1965).

2. Zampa, G.A., Altilia, F., Bracchetti, D., Geminiani, G.D., Borgatti, E., Odifreddi, M.T.: Studies on peripheral glucose metabolism using the experimental human forearm preparation. Diabetologia $3,35-46$ (1967).

3. Butterfield, W.J.H., Garratt, C.G., Wichelow, M.J.: Peripheral hormone action: Studies on the clearance and effect of $\left({ }^{131} \mathrm{I}\right)$ iodo-insulin in the peripheral tissues of normal, acromegalic and diabetic subjects. Clin. Sci. 24, 331-341 (1963).

4. Rasio, E.A.: The displacement of insulin from blood capillaries. Diabetologia 5, 416-419 (1969).

5. Berson, S.A., Yalow, R.S.: Some current controversies in diabetes research. Diabetes 14, 549-572 (1965).

6. Butterfield, W.J.H., Holling, H.E.: Peripheral glucose metabolism in fasting control subjects and diabetic patients. Clin. Sci. 18. 147-174 (1959).

7. Weisenfeld, S., Podolsky, S., Goldsmith, L., Ziff, L.: Adsorption of insulin to infusion bottles and tubing. Diabetes 17, 766-771 (1968).

8. Morgan, C.R., Lazarow, A.: Immunoassay of insulin: two antibody system. Plasma insulin levels of normal, sub-diabetic and diabetic rats. Diabetes 12, 115-126 (1963).

9. Whichelow, M.J., Wigglesworth, A., Cox, B.D., Butterfield, W.J.H., Abrams, M.E.: Critical analysis of blood sugar measurements in diabetes detection and diagnosis. Diabetes 16, 219-226 (1967).

10. Butterfield, W.J.H., Wichelow, M.J.: Effect of diet, sulfonylureas and phenformin on peripheral glucose uptake in diabetes and obesity. Lancet $1968 \mathrm{II}, 785-$ 788.

11. Baltzan, M.A., Andres, R., Cader, G., Zierler, K.L.: Heterogeneity of forearm metabolism. with special reference to free fatty acids. J. clin. Invest. 41, 116125 (1962).

12. Samols, E., Marks, V.: Interpretation of the intravenous glucose test. Lancet $1965 \mathrm{I}, 462-463$.

13. Meade, R.C., Kneubuhler, H.A., Barboriak, J.J., Schulte, W. J.: Absence of glucose response to physiologic levels of serum insulin. Diabetes 18, 397-401 (1969).

14. Zierler, K.L., Rabinowitz, D.: Effect of very small concentrations of insulin on forearm metabolism. Persistance of its action on potassium and free fatty acids without its effect on glueose. J. clin. Invest, 43, $950-962(1964)$. 
15. Pozefsky, T., Felig, P., Tobin, J.D., Soeldner, J.S., Cahill, G.F., Jr.: Amino acid balance across tissues of the forearm in postabsorptive man. Effects of insulin at two dose levels. J. clin. Invest. 48, 2273-2282 (1969).

16. Camu, F., Rasio, E.: Peripheral glucose uptake in relation to physiological levels of plasma and lymph insulin. Europ. J. clin. Invest. 2, 188-194 (1972).

17. Butterfield, W.J.H., Hanley, T., Wichelow, M.J.: Peripheral metabolism of glucose and free fatty acids during oral glucose tolerance tests. Metabolism 14, $851-866(1965)$.

18. Christensen, N.J., Orskov, H.: The relationship between endogenous serum insulin concentration and glucose uptake in the forearm muscles of non-diabetics. J. clin. Invest. 47, 1262-1268 (1968).

19. Butterfield, W.J.H., Abrams, M.A., St. John, D.J. B., Wichelow, M.J.: The intravenous glucose tolerance test. Peripheral disposal of the glucose load in controls and diabetics. Metabolism 16, 19-34 (1967).

20. Rasio, E.: Passage capillaire de l'insuline, p. 79. Bruxelles: Editions Arscia 1971.

Dr. E. Rasio

Dept. of Medicine

Metabolic Unit, Notre-Dame Hospital

1560 East Sherbrooke Str.

Montreal, P.Q./Canada 